\title{
Violence faced by nursing students in clinical practicals and its effects: A questionnaire survey
}

\author{
Yurdanur Dikmen ${ }^{1}$ \\ Dilek Yilmaz ${ }^{2}$ \\ Yasemin Yıldırım Usta ${ }^{3}$
}

\begin{abstract}
Nursing students may be exposed to all the kinds of violence in clinical practice areas.

Purpose: This study was conducted in order to determine the violence faced by nursing students in clinical practice areas, its effect on the gender factor and the feelings and behavior of students after the violence.

Methods: The study took place at a Foundation University in Bolu, Turkey over the period 20132014. The students' levels of voilence were assessed second, third and fourth years of the program. The research population consisted of the 256 students in the nursing department at the school. The sample group of the study consisted of a total of 220 students. Data were collected with a Student Information Form prepared by the researchers.

Results: $69.1 \%$ of students were exposed to violence during their practicals, and this mostly $(70.5 \%)$ took the form of verbal violence. $83.4 \%$ of female students reported that they were exposed to physical violence, $53.3 \%$ of them reported verbal violence and $60 \%$ reported that they were exposed to sexual violence, while $70.6 \%$ of the male students reported that they were exposed to gender discrimination. Among the forms of violence experienced, it was found that there was a statistically significant relationship $(\mathrm{p}<0.05)$ to gender.

Conclusions: These results showed that students were frequently exposed to violence in clinical areas, the form of violence was mostly verbal violence, the majority of male students were exposed to gender discrimination.
\end{abstract}

Keywords: Gender; male students; nursing students; training; violence.

\section{Introduction}

Violence in developed and developing countries continues to exist as one of the social problems of the 21st century (Kepenkçi \& Çinkir, 2005; Karabulutlu, 2015). Violence is defined by the World Health Organization (WHO) as the threat or deliberate use of force resulting in injury, death, psychological harm, developmental delay or neglect carried out by the person against himself, another person or a group (WHO, 2002). Violence in medical institutions is defined as a verbal or behavioral threat or physical or sexual assault which poses a risk to health care workers and which comes from patients, relatives or another person (Saines, 1999).

Violence is increasingly becoming part of our everyday lives, and the violence against health workers has been on the rise in recent years and is emerging as a major health problem ( $\mathrm{Al}$ et al.,

\footnotetext{
1 Assoc. Prof. Dr., Sakarya University, School of Health, Department of Nursing, nurdem35@gmail.com

2 Ph.D., Lecturer, Uludag University, School of Health, Department of Nursing, dilekkara15@,hotmail.com

${ }^{3}$ Assoc. Prof. Dr, Abant Izzet Baysal University, School of Health, Department of Nursing, yasemenyildirim@yahoo.com
} 
Dikmen, Y., Yılmaz, D., \& Yıldırım Usta, Y. (2016). Violence faced by nursıng students in clinical practicals and its effects: A questionnaire survey. Journal of Human Sciences, 13(3), 4380-4388. doi:10.14687/jhs.v13i3.4111

2012; Serin, Serin, Bakacak, \& Ölmez, 2015). It was reported that employees in the health sector are in 16 times more at risk of exposure to violence than employees who are working in other service sectors (Kingma, 2001). The WHO, the International Labor Organization (ILO), the International Council of Nurses (ICN) and international governmental organizations undertook a study in 2002 on collaboration against violence in workplaces in order to investigate violence in the health sector (Arslantaş, Adana, Bağcı \& Ayva, 2012). It was stated in the joint report of the study Workplace Violence in the Health Sector that more than half of health care workers were exposed to violence while they were working (Nau, Halfens, Needham \& Dassen, 2009).

When studies on the subject in the literature were examined according to professions, it was shown that those who suffered violence most often were nurses, the second were general practitioners, and after that other health staff (Ayranc1, Yenilmez, Gunay, \& Kaptanoğlu, 2002; Ayranc1, Yenilmez, Balci, \& Kaptanoglu, 2006; Shields \& Wilkins, 2009). In addition, it was reported in other studies that, because the majority of nurses were female and often worked in unsafe environments, their experience of violence was more than three times that of other professional groups (Keely, 2002; Arslantaş et al., 2007; Çelebioğlu, Akpinar, Küçükoğlu, \& Engin, 2010). In other studies conducted on the subject in different cultures, nurses seemed to have a high risk of exposure to violence in the workplace (Çelik, Çelik, Ağırbaş, \& Uğurluoğlu, 2007; Gökçe \& Dündar, 2008; Hahn et al., 2008; Lin \& Liu, 2005; Magnavita \& Heponiemi, 2011; Şenuzun \& Karadakovan, 2005; Uzun, 2003; Winstanley \& Whittington, 2004). Moreover, the violence that nurses face results in a reduction in the quality of care, demoralization and high stress levels, leaving the profession, an increase in job-related mistakes, a decrease in self-esteem and efficiency, and an increase in the number of mistakes while working (Taş \& Çevik, 2006; Uzun, Bağ, \& Özer, 2001).

In addition, nursing students who take most of their courses in health institutions may be exposed to all the kinds of violence during their training which medical personnel face during this period (Arslantaş et al., 2012; Özcan, Bilgin, Tülek, \& Boyacığlu, 2014). Practical training in clinics is an essential part of education in all nursing and health programs. It is necessary in order for nursing students to develop their knowledge, skills, competencies, attitudes and applied values. Clinical practice areas contribute to the development of students' cognitive, psychomotor and affective skills by allowing students to combine these skills (Chan, 2002). The efficiency of clinical training for providing the expected contribution is associated with the regulation of the clinical practice areas according to benefits for students. However, it has been stated in studies which have been conducted that nursing students are exposed to high levels of verbal violence in clinical practice areas (Arslantaş et al., 2012; Çelebioğlu et al., 2010; Çelik \& Bayraktar 2004; Ergöl \& Kürtüncü 2013; Lash, Kulakac, Buldukoglu \& Kukulu, 2006; Özcan et al., 2014; Ünal, Hisar \& Görgülü, 2012).

Because nursing students will be the future practitioners of the nursing profession, their education has vital importance for positive patient-care practices (Ünal et al., 2012). Therefore, determination of their response to the violence they experience can affect their perspective of the nursing profession and their selections in the area of employment after graduation (Curtis, Bowen, \& Reid, 2007). In addition, the identification of feelings and behavior of nursing students who have experienced violence is thought to be important for work to prevent violence. Besides, men entering the nursing profession in Turkey is very new: gender discrimination was eliminated with regulations enacted in 2007, and so today, men can be legal members of the nursing profession. However, the attitude in Turkish society is still not very positive towards male nurses. The results of our observations in clinical areas show that there can still be negative attitudes to male student nurses and thus male students may be exposed to gender discrimination. 
Dikmen, Y., Yilmaz, D., \& Yıldırım Usta, Y. (2016). Violence faced by nursıng students in clinical practicals and its effects: A questionnaire survey. Journal of Human Sciences, 13(3), 4380-4388. doi:10.14687/jhs.v13i3.4111

\section{Purpose}

This research was conducted to determine the experiences of nursing students of violence in practical areas, the effect of the gender factor on violence, and the students' feelings and behavior towards violence.

\section{Material and method}

\section{Design}

Descriptive and cross-sectional design.

\section{Setting and Sample}

The study was conducted over the academic years 2013-2014 at a School of Nursing of a Foundation University in Bolu, Turkey. The School of Nursing applies a four-year program of education. The first-year students had less clinical practice experience than the upper classes, and so they were not included in the study. Therefore, this research was carried out second, third and fourth years students who were studying at the nursing department of a university and who had clinical practice. The research population consisted of the 256 students in the nursing department at the same school. The sample group of the study consisted of a total of 220 students who were volunteers in the second year $(n=73)$, third year $(n=84)$ and fourth year $(n=63)$ (response rate: $86 \%$ ).

\section{Ethical Considerations}

The research permission was obtained from the University's Rector and the Head of School of Nursing (Decision No: 04, Number: 14.00.01/2014). The students were informed by the primary investigators about the nature of the study and were instructed that participation was voluntary and information was confidential and anonymous. The verbal consent of the students was obtained. The questionnaire was administered to the students in an observed classroom setting.

\section{Data Collection}

For the purpose of data collection, a Student Information Form was created by the researchers in accordance with the relevant literature. Demographic data including age, sex, and educational year and questions related to occupational violence including physical assault, physical, verbal, sexual menace.

Violence was separated into four categories, and participants were asked to answer questions according to each type of violence, how often the violence occurred, and who initiated the violence. Students were provided with the following definitions for each category:

1-Verbal violence: Words/gestures that are threatening, humiliating, repulsive or frightening, and/or being yelled or shouted at.

2-Physical violence: Hitting, pushing, kicking, scratching, spitting, hair pulling, slapping, beating, and/or being attacked with an object or attack to property.

3-Sexual violence: Words, tips, glances, and gestures with sexual content.

4-Gender discrimination: Any distinction, exclusion or restriction made on the basis of socially constructed gender roles and norms which prevents a person from enjoying full human rights.

\section{Data Analysis}

Data were analyzed by chi-square test and the number-percentage. Statistical significance was assumed to be $\mathrm{p}<0.05$. 
Dikmen, Y., Yılmaz, D., \& Yıldırım Usta, Y. (2016). Violence faced by nursing students in clinical practicals and its effects: A questionnaire survey. Journal of Human Sciences, 13(3), 4380-4388. doi:10.14687/jhs.v13i3.4111

\section{Results}

The distribution of the characteristics of the students who participated in the study is presented in Table 1 . The average age of the students was $21.72 \pm 1.28$ years, $67.3 \%$ of them were female, and 38.4\% were studying in the third year (Table 1).

Table I. Distribution of Students' Introductory Features

\begin{tabular}{lcc} 
& $\mathbf{n}$ & $\%$ \\
\hline Gender & 148 & 63.3 \\
Female & 72 & 32.7 \\
Male & & \\
Study Year & 73 & 33.2 \\
Second year & 84 & 38.2 \\
Third year & 63 & 28.6 \\
Fourth year & $\mathbf{2 2 0}$ & $\mathbf{1 0 0 . 0}$ \\
\hline Total & & \\
\hline
\end{tabular}

It was found that $69.1 \%$ of the students had been exposed to violence in the fields of practice, and that this violence was mostly (70.5\%) verbal violence (Table.2). $83.4 \%$ of the female students stated that they had been exposed to physical violence; $53.3 \%$ stated that the violence was verbal, and $60 \%$ that it was sexual violence. $70.6 \%$ of the male students reported that they had been exposed to gender discrimination. A statistically significant relationship was found between the violence experienced and gender $(\mathrm{p}<0.05)$ (Table.3).

Table 2. Distribution of Students by Exposure to Violence and Type of Violence

\begin{tabular}{lrr} 
& $\mathbf{n}$ & $\boldsymbol{\%}$ \\
\hline Exposure toViolence & 152 & 69.1 \\
Yes & 68 & 30.9 \\
No & 220 & 100.0 \\
Total & & \\
\hline Type of Violence & 6 & 3.9 \\
Physical Violence & 107 & 70.5 \\
Verbal Violence & 5 & 3.2 \\
Sexual Violence & 34 & 22.4 \\
Gender Discrimination & $\mathbf{1 5 2}$ & $\mathbf{1 0 0 . 0}$ \\
\hline Total & & \\
\hline
\end{tabular}

Table 3. Comparison by Gender of Type of Violence which Students Experienced

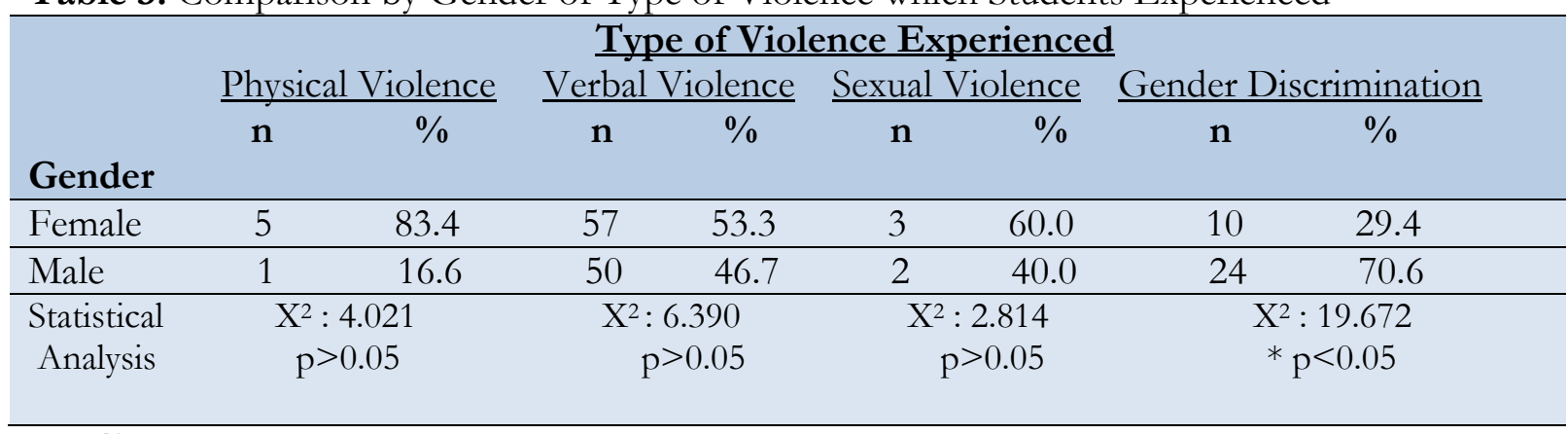

$X^{2}$, Chi-square test

*; statistical significance 
Dikmen, Y., Yilmaz, D., \& Yıldırım Usta, Y. (2016). Violence faced by nursıng students in clinical practicals and its effects: A questionnaire survey. Journal of Human Sciences, 13(3), 4380-4388. doi:10.14687/jhs.v13i3.4111

Table 4 shows the distribution of people who inflicted violence on students. Here, $44.1 \%$ of the students stated that they had been exposed to violence from nurses, and $35.4 \%$ stated that the violence was from patients and patients' relatives.

Table 4. Distribution of People who Engage in Violence in a Clinical Practice Setting

\begin{tabular}{lcc} 
People who Engage in Violence & $\mathbf{n}$ & $\mathbf{\%}$ \\
\hline Nurses & 67 & 44.1 \\
\hline Patients and their Relatives & 38 & 25.0 \\
\hline Doctors & 14 & 9.2 \\
\hline Other Healthcare Professionals & 19 & 12.5 \\
\hline Educators & 14 & 9.2 \\
\hline Total & 152 & 100.0 \\
\hline
\end{tabular}

The distribution of the physical, psychological and emotional impacts of violence on the students who were exposed to it is given in Table 5. Students stated that $17 \%$ of them had severe headaches, $18.3 \%$ had fatigue-weariness, $15.2 \%$ had anger-rage and $12.6 \%$ stated they had cried.

Table 5. Physical, Emotional, and Mental Effects of Violence Experienced by Students ( $\left.\mathrm{n}=644^{*}\right)$

\begin{tabular}{lcc} 
Effects & n* & \% \\
\hline Physical Effects & 110 & 17.0 \\
Severe headache & 66 & 10.2 \\
Stomach-ache & 28 & 4.3 \\
Nausea, vomiting & 118 & \\
\hline Mental Effects & 98 & 18.3 \\
Fatigue-disgust & 68 & 15.2 \\
Anger-rage & 40 & 10.5 \\
Anxiety & & 6.2 \\
Diminished self-confidence & 35 & 5.4 \\
\hline Emotional Effects & 81 & 12.6 \\
Occupation-hatred &
\end{tabular}

*Participants marked more than one choice

\section{Discussion}

As a result of this study, which was conducted to determine the feelings and behavior of nursing students to violence which they had experienced, it was found that $69.1 \%$ of the students had been exposed to violence and that the type of violence was $70.5 \%$ verbal violence and $22.4 \%$ gender discrimination (Table 2). In similar studies on the subject, the majority of nursing students in clinical areas were identified as having been exposed to verbal violence (Arslantaş et al., 2012; Çelebioğlu et al., 2010; Çelik \& Bayraktar, 2004; Ergöl \& Kürtüncü, 2013; Ferns \& Meerabeau, 2009; Hinchberger, 2009; Lash et al. 2006; Özcan et al., 2014; Ünal et al., 2012). Our research results are similar to the results of previous studies. When these results are analyzed together, it can be said that nursing students are more exposed to verbal violence.

It was determined that the majority of the female students who participated were faced with physical violence and the majority of male students $(70.6 \%)$ were determined as having been exposed to gender discrimination. A statistically significant relationship was found between the violence experiencedand gender. In a study conducted by Ergöl and Kürtüncü (2013) in Turkey, it was determined that $23.2 \%$ of female students and $55.7 \%$ of male students were exposed to gender discrimination and there was a statistically significant relationship between these groups. 
Dikmen, Y., Yılmaz, D., \& Yıldırım Usta, Y. (2016). Violence faced by nursıng students in clinical practicals and its effects: A questionnaire survey. Journal of Human Sciences, 13(3), 4380-4388. doi:10.14687/jhs.v13i3.4111

Our research results are similar to the results of that study. One of the indicators of gender discrimination is separation of jobs as men's and women's. Nursing in the health sector in Turkey is an area where more women are working intensively. In the literature, the nursing profession is reported as a women's profession, Turkish society reacts against male nurses, and patients are uncomfortable with receiving health care from male nurses (Kocaer et al., 2004; Taşç1, 2007). The exposure of male students to gender discrimination in our research is due to the response of the community against male students. On the other hand when studies on violence against health personnel are evaluated, it is reported that women are more exposed to verbal violence, and men are more exposed to physical violence (Acik et al. 2008; Ergör, Kılıç, \& Gürpınar, 2003; Piyal, Kaya, \& Çelen, 2007; Özcan et al., 2014). The fact that, unlike the results in the literature, the female students in our studyhad more exposure to physical violence than the male students can be interpreted as the female students being more vulnerable and to the violence perception being different between groups. Nursing schools started to accept male students in 2007 in Turkey. The presence of men in nursing, which is known as a female profession, is a situation that society has not yet adapted to. Therefore, it was observed that male students were discriminated against by patients and their relatives. This situation is expected to be adapted to in time as the numbers of male nursesincrease in practice areas.

$44.1 \%$ of the students who participated in the study stated that they were exposed to violence from nurses, and 35\% stated that it was from the patients and patients' relatives (Table 3). In similar studies conducted on the subject, it was determined that nursing students were mostly exposed to verbal violence from nurses (Dinmohammadi, Peyrovi, \& Mehrdad, 2014; Ergöl \& Kürtüncü, 2013; Longo, 2007; Longo \& Sherman, 2007; Magnativa \& Heponiemi, 2011). In other studies, it was found that students were mostly exposed to violence from patients and their relatives in clinical areas (Çelebioğlu et al. 2010; Özcan et al. 2014), from educators (Arslantaş et al., 2012; Ünal et al., 2012) and from classmates (Çelik \& Bayraktar, 2004). Nursing students in clinical areas are in communication more with nurses than with other medical staff. This can expose them to more violence from nurses against students. In addition, the exposure of nursing students to violence from nurses, who are expected to support their future colleagues, can indicate a problem in terms of the professional awareness of nurses (Çelebioğlu et al., 2010). Also, it would be an indication that nurses do not accept nursing students as members of the profession.

From the results of the research, $17 \%$ of the students stated that they had severe headache, $18.3 \%$ fatigue-weariness, and $15.2 \%$ anger-rage, and $12.6 \%$ stated that they cried (Table 5). In a study conducted by Magnavita and Heponiemi (2011) on Italian nurses and nursing students, it was found that $18.5 \%$ of them experienced anger, $38.9 \%$ fear, and $25.9 \%$ anxiety. In a study conducted by Özcan et al. (2014), it was stated that the majority of nursing students experienced anger, anxiety, lack of confidence, fear and shame. Similar results were found in studies conducted by Çelik and Bayraktar (2004). Although there were some proportional differences between the results of our study and the results of other studies, the response to the violence the students were exposed to - physical, psychological and emotional - is compatible overall with other study findings in the literature (Çelik \& Çelik, 2007; Çelik et al., 2007; Taş \& Çevik, 2006; Uzun et al., 2001).

\section{Limitations of the study}

There are some limitations in this study. Firstly, because this research was a cross-sectional study, it is impossible to generalize for all nursing students in the country. It is also difficult to report the experience of this kind of violence, because past experiences of violence can be traumatic. Therefore, the bias of participants may have influencedthe responses to the survey. There are some concerns about the data, although it was assumed to be heterogeneous. Cultural differences and perceptions may have affected the information about violent behavior. 
Dikmen, Y., Yılmaz, D., \& Yıldırım Usta, Y. (2016). Violence faced by nursıng students in clinical practicals and its effects: A questionnaire survey. Journal of Human Sciences, 13(3), 4380-4388. doi:10.14687/jhs.v13i3.4111

Therefore, because the nursing students' exposure to violence and their behavior and feelings were based on self-reporting, research findings have subjective features.

\section{Conclusions and recommendation}

It was found as a result of this research that the majority of nursing students in clinical areas were exposed to violence, the type of violence was mostly verbal violence and the violent individuals were mostly colleagues. In addition to these results, it was determined that the majority of male students were exposed to gender discrimination. In line with these results, it is suggested that violence against nursing students can be prevented by collaboration with educational institutions and application areas and by taking administrative measures. In addition, nursing students should be informed about violence and methods for coping with violence (communication techniques, developingempathy skills, risk management, etc.) during training. Also, it is important to inform society through mass media that gender does not affect the quality of nursing care and to conduct qualitative studies on the factors affecting the outlook for male nurses and nursing.

Conflict of interest: The authors declare no conflict of interest.

Acknowledgements: The authors would like to thank all students who helped them in performing this study.

\section{References}

Acik, Y., Deveci, S. E., Gunes, G., Gulbayrak, C., Dabak, S., Saka, G., ... Tokdemir, M. (2008). Experience of workplace violence during medical speciality training in Turkey. Occupational Medicine, 58, 361-366.

Al, B., Zengin, S., Deryal, Y., Gokşen, C., Arı, Y. D., Yıldırım, C. (2012). Increased violence towards health care staff. JAEM, 11, 115-24.

Arslantaş, H., Adana, F., Bağc1, S., Ayva, E. (2012). The relationships of violence nursing and midwifery students experience during their clinical practices with submissive behaviors and some variables. Florence Nightingale Journal of Nursing, 20, 53-61. (Original work published in Turkish). http://www.journals.istanbul.edu.tr/iufnhy/article/view/1023016537/1023015726.

Ayranc1, U., Yenilmez, C., Gunay, Y., Kaptanoğlu, C. (2002). The frequency of being exposed to violence in the various health institutions and health profession groups. Anatolian Journal of Psychiatry, 3, 147-154. http://docplayer.biz.tr/4330834-Cesitli-saglik-kurumlarinda-vesaglik-meslek gruplarinda-siddete-ugrama-sikligi-1.html

Ayranc1, U., Yenilmez, C., Balci, Y., Kaptanoglu, C. (2006). Identification of violence in Turkish health care settings. Journal of Interpersonal Violence, 21, 276-296.

Chan, D. S. K. (2002). Association between student learning outcomes from their clinical placement and their perceptions of the social climate of the clinical learning environment. International Journal of Nursing Studies, 39, 517-524.

Curtis, J., Bowen, I., Reid, A. (2007). You have no credibility: nursing students' experiences of horizontal violence. Nurse Education in Practice, 7, 156-163.

Çelebioğlu, A., Akpinar, R. B., Küçükoğlu, S., Engin, R. (2010). Violence experienced by Turkish nursing students in clinical settings: their emotions and behaviors. Nurse Education Today, 30, 687-691. 
Dikmen, Y., Yılmaz, D., \& Yıldırım Usta, Y. (2016). Violence faced by nursıng students in clinical practicals and its effects: A questionnaire survey. Journal of Human Sciences, 13(3), 4380-4388. doi:10.14687/jhs.v13i3.4111

Çelik, S. S., Bayraktar, N. (2004). A study of nursing student abuse in Turkey. Journal of Nurse Education, 43, 331-336.

Çelik, Y., Çelik, S. S. (2007). Sexual harassment against nurses in Turkey. Journal of Nursing Scholarship, 39, 200-206.

Çelik, S. Ş., Çelik, Y., Ağırbaş, İ., Uğurluoğlu, Ö. (2007). Verbal and physical abuse against nurses in Turkey. International Nursing Review 54, 359-366.

Dinmohammadi, M. R., Peyrovi, H., Mehrdad, N. (2014). Undergraduate student nurses' experiences in clinical environment: Vertical violence. Iran Journal of Nursing, 27, 83-93.

Ergöl, Ş., Kürtüncü, M. (2013). Violence Experienced By Nursing Students in Clinical Practice Settings. Journal of Higher Education and Science, 3, 65-69 (Original work published in Turkish). http://higheredu-sci.beun.edu.tr/pdf/pdf_HIG_1602.pdf

Ergör, A., Kilıç, B., Gürpınar, E. (2003). Occupational risks at health centers. Journal of Health of Occupational and Security, 16, 44-51.

Ferns, T., Meerabeau, E. (2009). Reporting behaviours of nursing students who have experienced verbal abuse. Journal of Advanced Nursing 65, 2678-2688.

Gökçe, T., Dündar, C. (2008). The frequency of exposing to violence and its effects on state and trait anxiety levels among the doctors and nurses working in Samsun psychiatry hospital. Journal of Inonu University Medical Faculty, 15, 25-28 (Original work published in Turkish). http:/ / file:///C:/Users/SYO3/Downloads/5000100453-5000142844-1-PB.pdf

Hahn, S., Zeller, A., Needham, I., Kok, G., Dassen, T., Halfens, R. J. G. (2008). Patient and visitor violence in general hospitals: a systematic review of the literature. Aggression and Violent Behavior, 13, 431-441. doi:10.1016/j.avb.2008.07.001

Hinchberger, P. A. (2009). Violence against female student nurses in the workplace. Nursing Forum Volume, 44, 37-46. doi: 10.1111/j.1744-6198.2009.00125.x.

Karabulutlu, Ö. (2015). Nursing students`views and experiences of violence. Journal of Hacettepe University Nursing Faculty, 26-36 (Original work published in Turkish). http://dergipark.ulakbim.gov.tr/hunhemsire/article/view/5000154793/5000140001

Keely, B. R. (2002). Recognition and prevention of hospital violence. Dimensions of Critical Care Nursing, 21, 236-241.

Kepenkci, Y.K., Çinkir, S. (2005). Bullying among Turkish high school students. Child Abuse \& Neglect, 1717, 1- 12.

Kingma, M. (2001). Workplace violence in the health sector: a problem of epidemic proportion. International Nursing Review, 48, 129-130.

Kocaer, Ü., Öztop, T., Usta, N., Gökçek, D., Bahçecik, N., Öztürk, H., Paslı, E. (2004). Male members in nursing). Journal of Ataturk University School of Nursing, 7, 23-29 (Original work published in Turkish). http://edergi.atauni.edu.tr/ataunihem/article/view/1025000265/1025000260

Lash, A. A., Kulakac, O., Buldukoglu, K., Kukulu, K. (2006). Verbal abuse of nursing and midwifery students in clinical settings in Turkey. Journal of Nursing Education, 45, 396-403.

Lin, Y., Liu, H. (2005). The impact of workplace violence on nurses in South Taiwan. International Journal of Nursing Studies, 42, 773-778.

Longo, J. (2007). Horizontal violence among nursing students. Archives of Psychiatric Nursing, 21, $177-178$. 
Dikmen, Y., Yilmaz, D., \& Yıldırım Usta, Y. (2016). Violence faced by nursıng students in clinical practicals and its effects: A questionnaire survey. Journal of Human Sciences, 13(3), 4380-4388. doi:10.14687/jhs.v13i3.4111

Longo, J., Sherman, R.O. (2007). Leveling horizontal violence. Nursing Management, 38, 34-37, 5051.

Magnativa, N., Heponiemi, T. (2011). Workplace violence against nursing students and nurses: an Italian experience. Journal of Nursing Scholarship, 43, 203-210.

Nau, J., Halfens, R., Needham, I., Dassen, T. (2009). The de-escalating aggressive behaviour scale: development and psychometric testing. Journal of Advanced Nursing, 65, 1956-1964.

Özcan, N. K., Bilgin, H., Tülek, Z., Boyacıoğlu, N. E. (2014). Nursing students' experiences of violence: a questionnaire survey. Journal of Psychiatric Nursing, 5, 49-56.

Piyal, B., Kaya, M., Çelen, U. (2007). Occupational correlates of fear of violence, harassment and threats among 112 emergency aid health workers (Ankara, Turkey). Anatolian Journal of Clinical Investigation, 1, 1-6.

Saines, J. C. (1999). Violence and aggression in A\&E: recommendations for action. Accident and Emergency Nursing, 7, 8-12.

Serin, H., Serin, S., Bakacak, M., Ölmez, S. (2015). Violence against health workers. Sted, 24, 109113. (Original work published in Turkish). http://www.ttb.org.tr/STED/images/ files/dergi/2015/3.pdf

Shields, M., Wilkins, K. (2009). Factors related to on-the-job abuse of nurses by patients. Health Reports, 20, 7-19.

Şenuzun, E. F., Karadakovan, A. (2005). Violence towards nursing staff in emergency departments in one Turkish city. International Nursing Review, 52, 154-160.

Taş, F., Çevik, Ü. (2006). The situation of exposed to violence of pediatric nurses in Konya. Journal of Anatolia Nursing and Health Sciences, 9, 62-68. (Original work published in Turkish). http://e-dergi.atauni.edu.tr/ataunihem/article/view/1025000488

Taşç1, K. D. (2007). Inpatients on Obstetrics and Gynecology Services Opinions about Male Nurses. Journal of Ataturk University School of Nursing, 10, 12-19. (Original work published in Turkish). http:// file:///C:/Users/SYO3/Downloads/577-2270-1-PB.pdf

Uzun, O. (2003). Perceptions and experiences of nurses in Turkey about verbal abuse in clinical settings. Journal of Nursing Scholarship, 35, 81-85.

Uzun, Ö., Bă̆, B., Özer, N. (2001). Impacts on nurses of verbal abuse in the workplace. Journal of Ataturk University School of Nursing, 4, 41-47. (Original work published in Turkish). http://e-dergi.atauni.edu.tr/ataunihem/article/viewFile/1025000113/1025000106

Ünal, S., Hisar, F., Görgülü, Ü. (2012). Assertiveness levels of nursing students who experience verbal violence during practical training. Contemporary Nurse, 42, 11-19.

Winstanley, S., Whittington, R. (2004). Aggression towards health care staff in a UK general hospital: variation among professionals and departments. Journal of Clinical Nursing, 13, 310.

World Health Organization (WHO)., (2002). World Report on Violenceand Health Geneva (Switzerland) 1-21. 